\title{
Oceanibaculum indicum gen. nov., sp. nov., isolated from deep seawater of the Indian Ocean
}

Correspondence

Zongze Shao

shaozz@163.com

\author{
Qiliang Lai, Jun Yuan, Changliang Wu and Zongze Shao
}

Key Laboratory of Marine Biogenetic Resources, Third Institute of Oceanography, State Oceanic Administration, Xiamen 361005, PR China

\begin{abstract}
A taxonomic study was carried out on strain $\mathrm{P} 24^{\top}$, which was isolated from a polycyclic aromatic hydrocarbon-degrading consortium, enriched from a deep-seawater sample collected from the Indian Ocean. The isolate was Gram-negative, rod-shaped, motile by means of a polar flagellum, moderately halophilic and capable of reducing nitrate to nitrite. Growth was observed at salinities of $0-9 \%$ and at temperatures of $10-42{ }^{\circ} \mathrm{C}$. The strain was unable to degrade Tween 80 or gelatin. The dominant fatty acids were $\mathrm{C}_{16: 0}\left(15.2 \%\right.$ of the total), $\mathrm{C}_{18: 0}(10.3 \%), \mathrm{C}_{18: 1} \omega 7 \mathrm{c}$ (52.0\%), $\mathrm{C}_{18: 1} 2-\mathrm{OH}(4.7 \%)$ and $\mathrm{C}_{19: 0} \mathrm{\omega} 8 \mathrm{c}$ cyclo $(4.7 \%)$. The $\mathrm{G}+\mathrm{C}$ content of the chromosomal DNA was 64.8 mol\%. 16S rRNA gene sequence comparisons showed that strain $\mathrm{P} 24^{\top}$ was related most closely to Thalassobaculum litoreum $\mathrm{CL}^{-G R 58}{ }^{\top}$ ( $92.7 \%$ similarity); levels of similarity between strain $\mathrm{P} 24^{\top}$ and type strains of recognized species in the family Rhodospirillaceae were all less than $90.8 \%$. Phylogenetic analyses based on 16S rRNA gene sequences showed that strain $\mathrm{P} 24^{\top}$ formed a distinct evolutionary lineage within the family Rhodospirillaceae. Strain $\mathrm{P} 24^{\top}$ could be distinguished from phylogenetically related genera based on differences in several phenotypic properties. On the basis of the phenotypic and phylogenetic data presented, strain $\mathrm{P} 24^{\top}$ is considered to represent a novel species of a new genus, for which the name Oceanibaculum indicum gen. nov., sp. nov. is proposed. The type strain is $\mathrm{P}_{2} 4^{\top}\left(=\mathrm{CCTCC}\right.$ AB $\left.208226^{\top}=\mathrm{LMG} 24626^{\top}=\operatorname{MCCC} 1 \mathrm{~A}^{\mathrm{T}} 2083^{\top}\right)$.
\end{abstract}

To investigate polycyclic aromatic hydrocarbon (PAH)degrading bacteria from deep seawater of the Indian Ocean, many bacterial strains were isolated and characterized taxonomically. The present study focuses on one of these isolates, designated strain $\mathrm{P} 24^{\mathrm{T}}$. Comparative $16 \mathrm{~S}$ rRNA gene sequence analysis indicated that strain $\mathrm{P} 24^{\mathrm{T}}$ formed a deep branch within the family Rhodospirillaceae. Accordingly, the aim was to determine the exact taxonomic position of strain $\mathrm{P} 24^{\mathrm{T}}$ by using a polyphasic characterization, including determination of phenotypic properties and detailed phylogenetic analysis based on 16S rRNA gene sequences.

Deep seawater was sampled with Niskin bottles attached to a CTD (conductivity, temperature and depth) circular rosette in December 2005 during the course of cruise DY105A of research vessel Da-Yang Yi-Hao. The sampling site (designated IR-CTD9-2) was at $70.0405^{\circ} \mathrm{E}, 25.3217^{\circ} \mathrm{S}$ on the Southwest Indian Ridge. Water depth at the site is $2488 \mathrm{~m}$; a water sample from $2468 \mathrm{~m}$ depth was used for

Abbreviation: $\mathrm{PAH}$, polycyclic aromatic hydrocarbon.

The GenBank/EMBL/DDBJ accession number for the 16S rRNA gene sequence of strain $\mathrm{P} 24^{\top}$ is EU656113.

Transmission electron micrographs of negatively stained cells of strain $\mathrm{P} 24^{\top}$ and a table giving the cellular fatty acid contents of strain $\mathrm{P} 24^{\top}$ and related genera are available as supplementary material with the online version of this paper. enrichment of PAH-degrading bacteria with $1 \%(\mathrm{v} / \mathrm{v})$ sterilized crude oil and a PAH mixture (final concentrations of 200 p.p.m. naphthalene, 200 p.p.m. phenanthrene, 200 p.p.m. anthracene and 200 p.p.m. pyrene; PAHs were dissolved in crude oil) as the carbon and energy source. Enrichment was undertaken on board immediately after sampling. Two months later, at our laboratory, $1 \mathrm{ml}$ of the enrichment culture was transferred into $100 \mathrm{ml}$ fresh medium containing (per litre) $1.0 \mathrm{~g} \quad \mathrm{NH}_{4} \mathrm{NO}_{3}, 0.5 \mathrm{~g}$ $\mathrm{KH}_{2} \mathrm{PO}_{4}$ and $2.8 \mathrm{mg} \mathrm{FeSO} 4.7 \mathrm{H}_{2} \mathrm{O}$, with the $\mathrm{PAH}$ mixture as the only carbon and energy source. $\mathrm{PAH}$ stock solution in chloroform was added to flasks to the same concentrations as above, and the flasks were then shaken at 160 r.p.m. for 2 days to evaporate the chloroform before inoculation. After 3 weeks incubation at $28{ }^{\circ} \mathrm{C}$ with shaking at 160 r.p.m., $1 \mathrm{ml}$ culture broth was transferred repeatedly to the same medium for further enrichment. Sequential transfers were performed every 4 weeks three times. Bacteria were isolated by using the plate screening method on $216 \mathrm{~L}$ medium (per litre seawater: $1.0 \mathrm{~g} \mathrm{CH}_{3} \mathrm{COONa}, 10.0 \mathrm{~g}$ tryptone, $2.0 \mathrm{~g}$ yeast extract, $0.5 \mathrm{~g}$ sodium citrate and $0.2 \mathrm{~g} \mathrm{NH}_{4} \mathrm{NO}_{3}$; $\mathrm{pH}$ 7.5). This medium was also used for morphological and biochemical characterization.

Genomic DNA was prepared according to the method of Ausubel et al. (1995); the 16S rRNA gene was amplified by 
Table 1. Differential characteristics between strain $\mathrm{P} 24^{\top}$ and related taxa

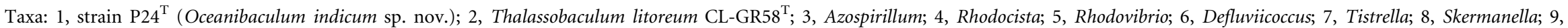
Inquilinus. Data for 2-9 were taken from Zhang et al. (2008). +, Positive; w, weakly positive; -, negative; v, variable; NA, data not available.

\begin{tabular}{|c|c|c|c|c|c|c|c|c|c|}
\hline Characteristic & 1 & 2 & 3 & 4 & 5 & 6 & 7 & 8 & 9 \\
\hline Colony colour & Grey & Cream-yellow & Pink, white & Red, pink & Pink, red & Beige & $\mathrm{NA}$ & Apricot & Pink \\
\hline Cell shape & Rod & Curved and rod & $\begin{array}{l}\text { Plump, vibrioid, } \\
\text { rod }\end{array}$ & Vibrioid, spiral & Vibrioid, spiral & Coccus & Rod & Rod & Rod \\
\hline Flagella* & MP & MP & $\mathrm{V}$ & MP & $\mathrm{MP}, \mathrm{BP}$ & Absent & MP & MP & $\mathrm{NA}$ \\
\hline Oxidase & - & + & + & $\mathrm{NA}$ & NA & - & + & + & $\mathrm{v}$ \\
\hline Catalase & + & + & + & $\mathrm{NA}$ & NA & + & + & + & + \\
\hline Gelatinase & - & + & $\mathrm{V}$ & NA & NA & $\mathrm{w}$ & + & - & $\mathrm{V}$ \\
\hline Temperature range $\left({ }^{\circ} \mathrm{C}\right)$ & $10-42$ & $10-35$ & $4-41$ & $25-47$ & $20-47$ & $20-30$ & $20-40$ & $10-37$ & $25-42$ \\
\hline $\begin{array}{l}\text { Temperature optimum } \\
\left({ }^{\circ} \mathrm{C}\right)\end{array}$ & $25-37$ & $30-35$ & $20-41$ & $31-45$ & $35-42$ & $25-30$ & 30 & 28 & NA \\
\hline $\mathrm{pH}$ range & $6-11$ & $7-9$ & $5-8.5$ & $5.7-8$ & $7-8$ & $5-8.5$ & $5-9$ & $\mathrm{NA}$ & $\mathrm{NA}$ \\
\hline $\mathrm{pH}$ optimum & $7-9$ & 8 & $5-7.2$ & $6.8-7$ & $7-8$ & $7.5-8$ & 7.4 & $\mathrm{NA}$ & $\mathrm{NA}$ \\
\hline $\begin{array}{l}\text { Salt tolerance } \\
(\%, w / v)\end{array}$ & $0-9$ & $1-10$ & $<5$ & $\mathrm{NA}$ & $3-24$ & $\mathrm{NA}$ & $<1$ & $<5$ & $<6$ \\
\hline $\begin{array}{l}\text { Bacteriochlorophyll } a \\
\text { Utilization of: }\end{array}$ & - & - & - & + & + & + & - & - & $\mathrm{NA}$ \\
\hline$N$-Acetylglucosamine & - & - & $\mathrm{V}$ & $\mathrm{NA}$ & $\mathrm{NA}$ & + & + & - & + \\
\hline L-Arabinose & - & + & $\mathrm{v}$ & $\mathrm{NA}$ & NA & + & + & + & - \\
\hline D-Glucose & - & - & $\mathrm{v}$ & - & - & + & NA & + & - \\
\hline Citrate & - & - & $\mathrm{v}$ & - & - & $\mathrm{NA}$ & NA & + & - \\
\hline Inositol & - & - & $\mathrm{v}$ & $\mathrm{NA}$ & NA & $\mathrm{NA}$ & NA & - & - \\
\hline D-Mannitol & - & - & $\mathrm{v}$ & - & - & $\mathrm{NA}$ & + & + & - \\
\hline L-Rhamnose & + & - & $\mathrm{v}$ & $\mathrm{NA}$ & NA & $\mathrm{NA}$ & NA & + & - \\
\hline Sucrose & - & + & V & - & - & $\mathrm{NA}$ & $\mathrm{NA}$ & $\mathrm{NA}$ & - \\
\hline $\begin{array}{l}\text { DNA G }+C \text { content } \\
(\mathrm{mol} \%)\end{array}$ & 64.8 & 68 & $64-71$ & $68.3-69.9$ & $66.2-68.1$ & 66 & 67.5 & 67.2 & 70.9 \\
\hline
\end{tabular}

${ }^{\star} \mathrm{BP}$, Bipolar; MP, monopolar. 
PCR by using the primers described by Liu \& Shao (2005). Sequences of related taxa were obtained from the GenBank database. Phylogenetic analysis was performed by using MEGA version 4 (Tamura et al., 2007) after multiple alignment of the data by DNAMAN (version 5.1; Lynnon Biosoft). Distances (distance options according to the Kimura two-parameter model) and clustering with the neighbour-joining method of Saitou \& Nei (1987) and minimum-evolution method of Rzhetsky \& Nei (1992, 1993) were determined by using bootstrap values based on 1000 replications. Data for the minimum-evolution clustering are not shown as the results were similar to those with the neighbour-joining method.

General cell morphology was studied under an Olympus inverted microscope by using 1-day-old cultures on $216 \mathrm{~L}$ agar. For electron microscopy, exponential-phase cells were harvested, subsequently suspended and absorbed on a Formvar-carbon-coated grid, then stained with phosphotungstic acid (see Supplementary Fig. S1 in IJSEM Online). Tests for the Gram reaction, catalase and oxidase activities, lipase (Tween 80) and amylase were carried out according to Dong \& Cai (2001). The optimal growth temperature was determined over the range $4-55{ }^{\circ} \mathrm{C}$ on $216 \mathrm{~L}$ agar. Tolerance to $\mathrm{NaCl}$ was tested by using Luria-Bertani (LB) medium (Sambrook et al., 1989) supplemented with $\mathrm{NaCl}$ at concentrations of $0,0.5,1,2,3,4,5,6,7,8,9,10,12,15$, 18 and $20 \%(\mathrm{w} / \mathrm{v})$. Antibiotic susceptibility tests were performed by the disc diffusion method as described by Shieh et al. (2003). Bacteriochlorophyll a content was determined as described by Biebl et al. (2005). Other biochemical tests were carried out by using API 20NE and API ZYM strips (bioMerieux) according to the manufacturer's instructions, and by using the Biolog GN2 microplate system according to Ivanova et al. (1998). The G + C content of the chromosomal DNA was determined according to the method described by Mesbah \& Whitman (1989) by using reversed-phase HPLC. Fatty acids in whole cells grown on $216 \mathrm{~L}$ plate medium at $28{ }^{\circ} \mathrm{C}$ for $48 \mathrm{~h}$ were extracted, saponified and esterified; this was followed by GC analysis of the fatty acid methyl esters according to the instructions of the MIDI system (Sasser, 1997). These results are given in the species description below and in Table 1 .

A nearly full-length $16 \mathrm{~S}$ rRNA gene sequence (1451 nt) of strain $\mathrm{P} 24^{\mathrm{T}}$ was determined. Phylogenetic analysis indicated that strain $\mathrm{P} 24^{\mathrm{T}}$ belonged to the family Rhodospirillaceae (Fig. 1). In the phylogenetic tree based on the neighbour-joining algorithm, strain $\mathrm{P} 24^{\mathrm{T}}$ joined the clade comprising Thalassobaculum litoreum CL-GR58 ${ }^{\mathrm{T}}$, with which it shared highest 16S rRNA gene sequence similarity $(92.7 \%)$. Strain $\mathrm{P} 24^{\mathrm{T}}$ showed $90.8 \% 16 \mathrm{~S}$ rRNA gene sequence similarity to Skermanella aerolata DSM $18479^{\mathrm{T}}$ and $79.3-89.1 \%$ to the type strains of other type species in the family Rhodospirillaceae used in the phylogenetic analysis (Fig. 1). In addition, BLASTN results showed that strain $\mathrm{P} 24^{\mathrm{T}}$ shared highest $16 \mathrm{~S}$ rRNA gene sequence similarity $(98.7 \%)$ with a bacterium, designated strain SL3.14, from the Silver Lake throughflow playa in California, USA (Navarro et al., 2009).

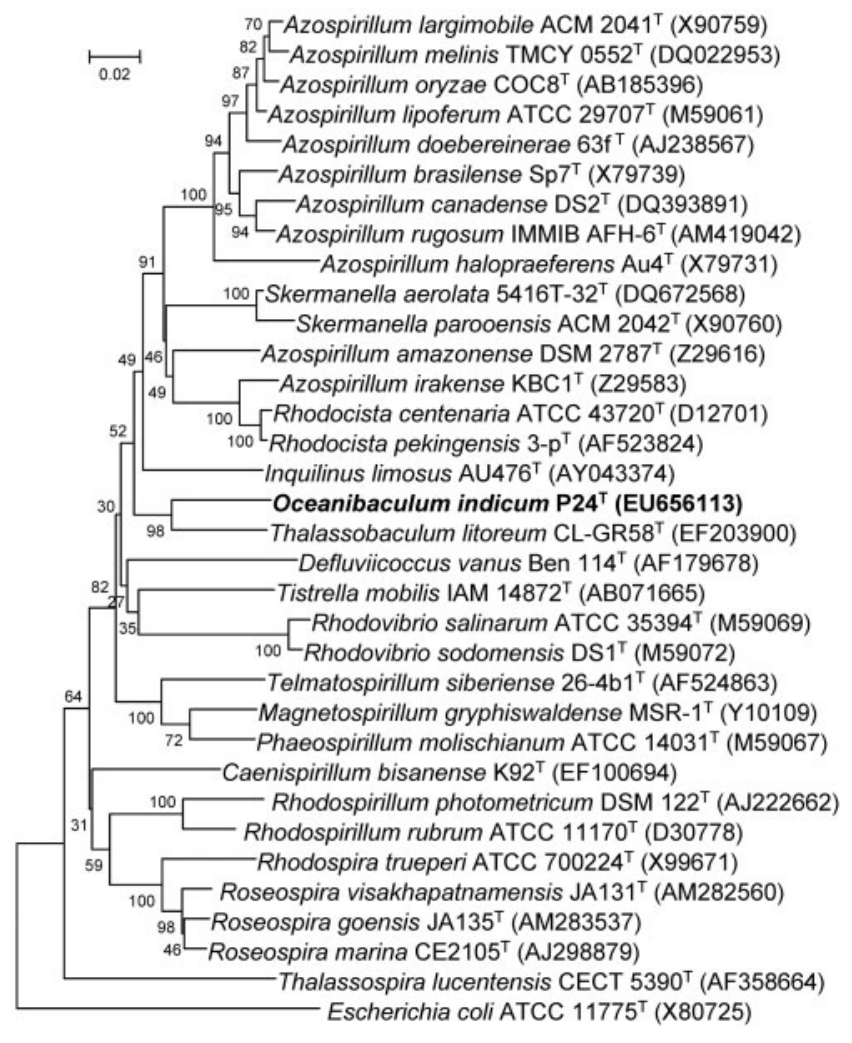

Fig. 1. Neighbour-joining tree showing the phylogenetic positions of strain $\mathrm{P} 24^{\top}$ and representatives of some related taxa, based on 16S rRNA gene sequences. Bootstrap values (expressed as percentages of 1000 replications) are shown at branch points. Bar, 0.02 nucleotide substitution rate $\left(K_{\text {nuc }}\right)$ units.

Although strain $\mathrm{P} 24^{\mathrm{T}}$ and Thalassobaculum litoreum CLGR $58^{\mathrm{T}}$ form a separate clade in the family Rhodospirillaceae with high bootstrap support ( $98 \%$, Fig. 1), the novel strain was not classified within the genus Thalassobaculum as it showed important differences in several phenotypic properties. Strain $\mathrm{P} 24^{\mathrm{T}}$ was negative for oxidase, gelatinase and amylase, in contrast to the results for Thalassobaculum litoreum CL-GR58 ${ }^{\mathrm{T}}$ (see Table 1). In addition, these two strains differed in ten enzyme reactions in API ZYM tests and in sensitivity to seven antibiotics (see Table 2). Moreover, strain $\mathrm{P} 24^{\mathrm{T}}$ showed differences from Thalassobaculum litoreum CL-GR58 ${ }^{\mathrm{T}}$ in fatty acid composition, such as the proportion of $\mathrm{C}_{17: 0}(0.4$ vs. $12.2 \%$, respectively) and $\mathrm{C}_{18: 0}(10.3$ vs. $2 \%)$, and the presence of $\mathrm{C}_{16: 0} \quad 3-\mathrm{OH}, \mathrm{C}_{18: 0} \quad 3-\mathrm{OH}$ and $\mathrm{C}_{18: 1} \quad 2-\mathrm{OH}$ (see Supplementary Table S1 in IJSEM Online). Phenotypically, strain $\mathrm{P} 24^{\mathrm{T}}$ could be differentiated from members of the genera Azospirillum, Tistrella and Skermanella, which are positive for oxidase and have low salt tolerance $(<5 \%$, w/v); it could also be differentiated from members of the genera Rhodocista, Rhodovibrio and Defluviicoccus based on several phenotypic features (colony colour, cell shape and temperature range for growth) and 
Table 2. Differential characteristics between strain $\mathrm{P} 24^{\top}$ and Thalassobaculum litoreum

Strains: 1, $\mathrm{P} 24^{\mathrm{T}} \quad$ (Oceanibaculum indicum sp. nov.); 2, Thalassobaculum litoreum CL-GR58 ${ }^{\mathrm{T}}$. + , Positive; $\mathrm{w}$, weakly positive; -, negative.

\begin{tabular}{|lcc|}
\hline Characteristic & $\mathbf{1}$ & $\mathbf{2}$ \\
\hline Reaction to antimicrobial agents & & \\
Ampicillin $(10 \mu \mathrm{g})$ & - & + \\
Gentamicin $(10 \mu \mathrm{g})$ & - & + \\
Erythromycin $(15 \mu \mathrm{g})$ & - & + \\
Penicillin G $(10 \mu \mathrm{g})$ & - & + \\
Tetracycline $(30 \mu \mathrm{g})$ & - & + \\
Vancomycin $(30 \mu \mathrm{g})$ & - & + \\
Polymyxin B $(30 \mathrm{IU})$ & + & - \\
API ZYM data & & \\
Esterase $(\mathrm{C} 4)$ & $\mathrm{w}$ & + \\
Cystine aminopeptidase & $\mathrm{W}$ & - \\
Naphthol-AS-BI-phosphoamidase & $\mathrm{w}$ & + \\
$\alpha$-Galactosidase & - & $\mathrm{W}$ \\
$\beta$-Galactosidase & - & $\mathrm{w}$ \\
$\alpha$-Glucosidase & - & + \\
$\beta$-Glucosidase & - & + \\
$N$-Acetyl- $\beta$-glucosaminidase & - & + \\
$\alpha$-Mannosidase & - & $\mathrm{w}$ \\
$\alpha$-Fucosidase & - & $\mathrm{w}$ \\
& & \\
\hline
\end{tabular}

from members of the genus Inquilinus by its pink colony colour, DNA G $+\mathrm{C}$ content difference $(>6 \mathrm{~mol} \%)$ and low salt tolerance $(<6 \%$, w/v) (Table 1$)$.

The low levels of 16S rRNA gene sequence similarity between strain $\mathrm{P} 24^{\mathrm{T}}$ and all other members of the family Rhodospirillaceae, together with differential phenotypic properties (Table 1), suggest that strain $\mathrm{P} 24^{\mathrm{T}}$ represents a novel species of a new genus within the family Rhodospirillaceae, for which the name Oceanibaculum indicum gen. nov., sp. nov. is proposed.

\section{Description of Oceanibaculum gen. nov.}

Oceanibaculum (O.ce.a'ni.ba'cu.lum. Gr. n. oceanus ocean; L. neut. n. baculum stick; N.L. neut. n. Oceanibaculum rodshaped bacterium from the ocean).

Cells are rod shaped, motile by means of a single polar flagellum, Gram-negative, oxidase-negative, catalase-positive, capable of reducing nitrate to nitrite, but not capable of denitrification. The dominant fatty acids are $\mathrm{C}_{16: 0}$, $\mathrm{C}_{18: 0}, \quad \mathrm{C}_{18: 1} \omega 7 c, \mathrm{C}_{18: 1} \quad 2-\mathrm{OH}$ and $\mathrm{C}_{19: 0} \omega 8 c$ cyclo. Bacteriochlorophyll $a$ is not detected. The type species is Oceanibaculum indicum.

\section{Description of Oceanibaculum indicum sp. nov.}

Oceanibaculum indicum (in.di'cum. L. adj. indicum referring to the Indian Ocean, from where the type strain was isolated).
Exhibits the following properties in addition to those given in the genus description. Cells are 2.3-2.5 $\mu \mathrm{m}$ long and $0.6-1.5 \mu \mathrm{m}$ wide. Negative for lipase (Tween 80 ), amylase, urease, gelatinase, arginine dihydrolase and indole production. On 216L agar, forms smooth grey colonies with regular edges that are $1-2 \mathrm{~mm}$ in diameter after $72 \mathrm{~h}$ incubation at $28{ }^{\circ} \mathrm{C}$, non-pigmented and slightly raised in the centre. Moderately halophilic; grows in the presence of $0-9 \% \mathrm{NaCl}$ (optimum, 0.5-7\%). Grows at $10-42{ }^{\circ} \mathrm{C}$ (optimum, $25-37{ }^{\circ} \mathrm{C}$ ), but no growth is observed after 7 days at 4 or $45{ }^{\circ} \mathrm{C}$. Unable to ferment glucose. Sensitive to chloramphenicol (30 $\mu \mathrm{g}$ per disc; Oxoid), ciprofloxacin $(5 \mu \mathrm{g})$, co-trimoxazole $(25 \mu \mathrm{g})$, kanamycin $(30 \mu \mathrm{g})$, neomycin $(10 \mu \mathrm{g})$, polymyxin $\mathrm{B}(30 \mathrm{IU})$ and streptomycin $(10 \mu \mathrm{g})$, but resistant to ampicillin $(10 \mu \mathrm{g})$, carbenicillin $(100 \mu \mathrm{g})$, cefalexin $(30 \mu \mathrm{g})$, cefazolin $(30 \mu \mathrm{g})$, cefoperazone $(30 \mu \mathrm{g})$, cephradin $(30 \mu \mathrm{g})$, clindamycin $(2 \mu \mathrm{g})$, erythromycin $(15 \mu \mathrm{g})$, furazolidone $(15 \mu \mathrm{g})$, gentamicin $(10 \mu \mathrm{g})$, lincomycin $(2 \mu \mathrm{g})$, metronidazole $(5 \mu \mathrm{g})$, minocycline $(30 \mu \mathrm{g})$, norfloxacin $(10 \mu \mathrm{g})$, ofloxacin $(5 \mu \mathrm{g})$, oxacillin $(1 \mu \mathrm{g})$, penicillin $\mathrm{G}(10 \mu \mathrm{g})$, piperacillin $(100 \mu \mathrm{g})$, rifampicin $(5 \mu \mathrm{g})$, ceftriaxone $(30 \mu \mathrm{g})$, tetracycline $(30 \mu \mathrm{g})$, vancomycin $(30 \mu \mathrm{g})$ and doxycycline $(30 \mu \mathrm{g})$. In API ZYM tests, positive for acid phosphatase, alkaline phosphatase, leucine aminopeptidase and valine aminopeptidase, weakly positive for cystine aminopeptidase, esterase (C4), esterase lipase (C8), lipase (C14) and naphthol-ASBI-phosphoamidase, but negative for trypsin, $\alpha$-chymotrypsin, $\alpha$-galactosidase, $\beta$-galactosidase, $\beta$-glucuronidase, $\alpha$-glucosidase, $\beta$-glucosidase, $N$-acetyl- $\beta$-glucosaminidase, $\alpha$-mannosidase and $\alpha$-fucosidase. Among 95 substrates in the Biolog GN2 system, positive for bromosuccinic acid, Darabitol, D-saccharic acid, glycyl L-glutamic acid, L-alanine, L-glutamic acid, L-proline, L-pyroglutamic acid, L-rhamnose, succinamic acid, Tween 40 and $\alpha$-ketoglutaric acid. The DNA G +C content of the type strain is $64.8 \mathrm{~mol} \%$. Table 1 shows characteristics that can be used to distinguish the type strain from related species.

The type strain, $\mathrm{P} 24^{\mathrm{T}}$ (=CCTCC AB $208226^{\mathrm{T}}=\mathrm{LMG}$ $24626^{\mathrm{T}}=$ MCCC $\left.1 \mathrm{~A} 02083^{\mathrm{T}}\right)$, was isolated from deep seawater of the Indian Ocean.

\section{Acknowledgements}

This work was financially supported by the National Infrastructure of Natural Resources for Science and Technology Program of China (No. 2005DKA21209), COMRA program (No. DYXM115-02-2-05), National Basic Research Program of China (No. 2004CB719601) and National Natural Science Foundation of China (30670051; 40376041).

\section{References}

Ausubel, F. M., Brent, R., Kingston, R. E., Moore, D. D., Seidman, J. G., Smith, J. A. \& Struhl, K. (editors) (1995). Short Protocols in Molecular Biology: a Compendium of Methods from Current Protocols in Molecular Biology, 3rd edn. New York: Wiley.

Biebl, H., Allgaier, M., Tindall, B. J., Koblizek, M., Lünsdorf, H., Pukall, R. \& Wagner-Döbler, I. (2005). Dinoroseobacter shibae gen. 
nov., sp. nov., a new aerobic phototrophic bacterium isolated from dinoflagellates. Int J Syst Evol Microbiol 55, 1089-1096.

Dong, X.-Z. \& Cai, M.-Y. (2001). Determinative Manual for Routine Bacteriology. Beijing: Scientific Press (English translation).

Ivanova, E. P., Kiprianova, E. A., Mikhailov, V. V., Levanova, G. F., Garagulya, A. D., Gorshkova, N. M., Vysotskii, M. V., Nicolau, D. V., Yumoto, N. \& other authors (1998). Phenotypic diversity of Pseudoalteromonas citrea from different marine habitats and emendation of the description. Int J Syst Bacteriol 48, 247-256.

Liu, C. \& Shao, Z. (2005). Alcanivorax dieselolei sp. nov., a novel alkane-degrading bacterium isolated from sea water and deep-sea sediment. Int J Syst Evol Microbiol 55, 1181-1186.

Mesbah, M. \& Whitman, W. B. (1989). Measurement of deoxyguanosine/thymidine ratios in complex mixtures by high-performance liquid chromatography for determination of the mole percentage guanine + cytosine of DNA. J Chromatogr 479, 297-306.

Navarro, J. B., Moser, D. P., Flores, A., Ross, C., Rosen, M. R., Dong, H., Zhang, G. \& Hedlund, B. P. (2009). Bacterial succession within an ephemeral hypereutrophic Mojave Desert playa Lake. Microb Ecol 57, 307-320.

Rzhetsky, A. \& Nei, M. (1992). A simple method for estimating and testing minimum evolution trees. Mol Biol Evol 9, 945-967.
Rzhetsky, A. \& Nei, M. (1993). Theoretical foundation of the minimum-evolution method of phylogenetic inference. Mol Biol Evol 10, 1073-1095.

Saitou, N. \& Nei, M. (1987). The neighbor-joining method: a new method for reconstructing phylogenetic trees. Mol Biol Evol 4, 406425.

Sambrook, J., Fritsch, E. F. \& Maniatis, T. (1989). Molecular Cloning: a Laboratory Manual, 2nd edn. Cold Spring Harbor, NY: Cold Spring Harbor Laboratory.

Sasser, M. (1997). Identification of bacteria by gas chromatography of cellular fatty acids, MIDI Technical Note 101. Newark, DE: MIDI Inc.

Shieh, W. Y., Chen, Y.-W., Chaw, S.-M. \& Chiu, H.-H. (2003). Vibrio ruber sp. nov., a red, facultatively anaerobic, marine bacterium isolated from sea water. Int J Syst Evol Microbiol 53, 479-484.

Tamura, K., Dudley, J., Nei, M. \& Kumar, S. (2007). MEGA4: molecular evolutionary genetics analysis (MEGA) software version 4.0. Mol Biol Evol 24, 1596-1599.

Zhang, G. I., Hwang, C. Y. \& Cho, B. C. (2008). Thalassobaculum litoreum gen. nov., sp. nov., a member of the family Rhodospirillaceae isolated from coastal seawater. Int J Syst Evol Microbiol 58, 479485 . 